\title{
Diffusion Weighted MRI: A Practical and Quick Approach to Evaluate Brain Death
}

\author{
Ihsan Nuri Akpinar ${ }^{1 *}$, Bediha Aygun ${ }^{2}$, Nuri Cagatay Cimsit ${ }^{1}$, Ozlem Turkoglu ${ }^{3}$ \\ ${ }^{1}$ Department of Radiology, Medical Faculty, Marmara Univeristy, Istanbul, Turkey \\ ${ }^{2}$ Department of Radiology, Haydarpasa Numune Education and Research Hospital, Istanbul, Turkey \\ ${ }^{3}$ Department of Radiology, Dr. Lutfi Kirdar Kartal Education and Research Hospital, Istanbul, Turkey \\ Email: ${ }^{*}$ ihsannuriakpinar@yahoo.com
}

Received 8 February 2015; accepted 28 March 2015; published 7 April 2015

Copyright (C) 2015 by authors and Scientific Research Publishing Inc.

This work is licensed under the Creative Commons Attribution International License (CC BY). http://creativecommons.org/licenses/by/4.0/

(c) (i) Open Access

\section{Abstract}

It is significantly important to define brain death with greater precision in terms of timing and accuracy. While in the past determination of brain death is simply based on conventional angiography, now with major technological advances the Diffusion-weighted MRI is a new method sensitive to cerebral ischemia which gives on the molecular level the deeply ischemic nature of the changes. Its value in brain death has been shown in various studies. In our study, we did a comparative overview of diffusion-weighted imaging (DWI) with and magnetic resonance angiography (MRA) considering the contribution of ADC measurements from brain parenchyma, in the patients diagnosed with brain death by clinical criteria. We studied 16 brain deaths in serial studies, in which there is a prominent difference between the white and gray matter ADC values on diffusion MRI. In the postmortem brains, ADC values comparing with the normal brain parenchyma, were reduced $65 \%$ in white matter and $42 \%$ in gray matter. Also, the patients' ADC values of gray and white matter were significantly lower than those of irreversible brain-ischemia patients' in ADC values. In comparison to most of the other studies, in our study population studied is large, in which is a comprehensive study that results consistent with the literature. As a result we propose that in the definition of brain death Diffusion MRI and ADC measurements are reliable to show diffuse ishemic changes of brain parenchyma.

\section{Keywords}

DWI, MRI, Brain Death, Transplantation

\footnotetext{
${ }^{*}$ Corresponding author.

How to cite this paper: Akpinar, I.N., Aygun, B., Cimsit, N.C. and Turkoglu, O. (2015) Diffusion Weighted MRI: A Practical and Quick Approach to Evaluate Brain Death. International Journal of Medical Physics, Clinical Engineering and Radiation Oncology, 4, 113-123. http://dx.doi.org/10.4236/ijmpcero.2015.42015
} 


\section{Introduction}

Historically, it even takes places in the old writings that the brain is the first organ that will lose its viability after the death. Obtaining organs from donors after cardiac death was the approach that was generally followed in the 1960s and that approach did not allow for organs other than the liver and kidneys to be procured in most cases. With increasing demand of solid-organ transplantations, brain death criteria was established. Today, pathophysiological changes that leads irreversible loss of functioning of the whole brain is accepted as the sole criterion of brain death. Since 1968, a brain-based definition of death was proposed by Harvard Medical School and named as Harvard criteria [1] that became widely accepted. Various studies have been undertaken to determine which distinct signs are needed to call "brain death" on the basis of both clinical and confirmatory tests. Unlike the past, supportive testing is not required to help diagnosis in situations in which the clinical determination is inadequate. Today it is used to the diagnosis of brain death quicker.

MRI and MRA guidance for diagnosis of the brain death is used since the early 1990s. In the year 2000, first case report on diffusion-weighted imaging (DWI) in brain death by Lövblad and Bassetti was reported [2]. Following this report, limited number of studies were reported about the results of deep ischemia in the molecular level which were caused by functional and anatomical changes that led to brain death.

In our study, we evaluated the efficiency and diagnostic value of diffusion weighted MR in making the diagnosis of brain death.

\section{Material and Method}

The study was carried out between June 2007 and October 2013, sixteen brain death patients (male/female: 8/8; mean age: $37.37 \pm 16.58$ years) were evaluated with post mortem MRI and MRA methods. Apparent diffusion coefficient (ADC) values in the normal brain parenchyma were calculated in ten patients who were examined with cranial MRI for various reason without any known neural parenchymal pathology. We performed the study with 1.5T MR (Intera, Philips Medical Systems, Holland) with a head coil. MR compatible ventilation device was used in all cases, no contrast material.

Seven of sixteen comatose patients were brain trauma patients (two car and one motor vehicle accident, three accidental falling, one shotgun), three of them were spontaneous intracranial bleeding, one meningitis following MCA aneurysm operation, one large MCA infarction, one hypertension releated subarachnoid hemorrhage, one viral ensephalitis, one acute anterior myocardial enfarction, and one operated intracranial mass. Patients with their medical history, radiological signs, and clinical results are presented in Table 1.

\section{MR Imaging Method and Interpretation of Images}

MRI examinations were performed with axial T2W, axial FLAIR, sagital T2W, and coronal T1W images, and 3D gradient echo arteriography. An additional sequence of DWI was performed at b values of 0 and $1000 \mathrm{~s} / \mathrm{mm}^{2}$. The visual and quantitative results of ADC maps were obtained.

Single-shot echo-planar imaging (EPI) measurements supplied DWI and diffusion measurements were made using separately applied $\mathrm{x}, \mathrm{y}$, and $\mathrm{z}$ gradients. To minimize the effects of diffusion anisotrophy, the mean value of images obtained in the $\mathrm{x}, \mathrm{y}$, and $\mathrm{z}$ directions were automatically created by the device and trace (isotropic) images created.

First of all, conventional MR sequences and MRA images were evaluated. Interpretations of diffusionweighted images were done after region of interest (ROI) was determined.

The ADC values were calculated from the images between $0.81-1.03 \mathrm{~mm}^{2}$ pixel in volume. In ADC maping the measurements, were derived from multiplication wth $10^{-3} \mathrm{~mm}^{2} / \mathrm{sn}$ according to Stejskal-Tanner formula.

Since ADC can be falsely elevated by partial volume averaging of cerebrospinal fluid (CSF) with parenchyma, we paid attention to measure the field by excluding CSF. We considered the statement that ADC measurements of white matter are smaller when measured perpendicular to the main fiber direction than when measured in the direction of the fiber bundle [3].

\section{Statistical Analyses}

We used SPSS 12.0.2 for statistical analysis. We used the descriptive statistical methods (mean, standard deviation, degrees of freedom) and the Independent-Samples Student T Test to compare sets of quantitative data. Re- 
Table 1. Patients and findings. * ICF (intracranial flow), ${ }^{* *}$ SAH (subarachnoidal hemorrhage).

\begin{tabular}{|c|c|c|c|c|c|}
\hline Patient & History & MR signs & MRA signs & $\begin{array}{c}\text { ADC value } \\
\left(\mathrm{mm}^{2} / \mathrm{sn} \times 10^{-3}\right)\end{array}$ & Clinic result \\
\hline $56 / \mathrm{M}$ & $\begin{array}{l}\text { Meningitis after } \\
\text { MCA aneursym } \\
\text { operation }\end{array}$ & $\begin{array}{l}\text { Diffuse brain edema, } \\
\text { tonsillar herniation, } \\
\text { brainstem compression }\end{array}$ & $\operatorname{ICF}^{*}(-)$ & $\begin{array}{l}\text { White matter: } 0.262 \\
\text { Gray matter: } 0.490 \\
\text { cerebellum: } 0.445\end{array}$ & $\begin{array}{l}\text { Died within } \\
24 \text { hours }\end{array}$ \\
\hline $46 / \mathrm{K}$ & MCA enfarct & $\begin{array}{l}\text { Diffuse brain edema, subfalcine, } \\
(7 \mathrm{~mm}) \text { and tonsiller herniation, } \\
\text { brainstem compresion }\end{array}$ & $\operatorname{ICF}(-)$ & $\begin{array}{l}\text { White matter: } 0.221 \\
\text { Gray matter: } 0.463 \\
\text { cerebellum: } 0.320\end{array}$ & $\begin{array}{l}\text { Died within } \\
4 \text { days }\end{array}$ \\
\hline $39 / E$ & $\begin{array}{l}\text { Gunshot } \\
\text { wound }\end{array}$ & $\begin{array}{l}\text { Traumatic signs; traumatic SAH, } \\
\text { diffuse brain edema, tonsiller } \\
\text { herniation, brainstem compresion }\end{array}$ & $\operatorname{ICF}(-)$ & $\begin{array}{l}\text { White matter: } 0.262 \\
\text { Gray matter: } 0.460 \\
\text { Serebellum: } 0.291\end{array}$ & $\begin{array}{l}\text { Died within } \\
24 \text { hrs }\end{array}$ \\
\hline $10 / \mathrm{E}$ & Fall accidents & $\begin{array}{l}\text { Traumatic signs; SAH, subfalcine SAH, } \\
\text { subfalcine (10 mm) tonsiller herniastion, } \\
\text { diffüz edema, brain stem compresion. }\end{array}$ & $\operatorname{ICF}(-)$ & $\begin{array}{l}\text { White matter: } 0.291 \\
\text { Gray matter : } 0.495 \\
\text { cerebellum: } 0.402\end{array}$ & $\begin{array}{l}\text { Died within } \\
48 \text { hrs }\end{array}$ \\
\hline $47 / \mathrm{E}$ & Fall accidents & $\begin{array}{l}\text { Traumatic signs; SAH, diffuse brain } \\
\text { edema, tonsillar herniation, } \\
\text { brainstem compresion. }\end{array}$ & $\operatorname{ICF}(-)$ & $\begin{array}{l}\text { White matter: } 0.219 \\
\text { Gray matter: } 0.442 \\
\text { cerebellum: } 0.290\end{array}$ & $\begin{array}{l}\text { Died within } \\
36 \text { hrs }\end{array}$ \\
\hline $\begin{array}{c}51 / \mathrm{K} \\
\text { (Figure 1) }\end{array}$ & $\begin{array}{l}\text { Hipertansive } \\
\text { SAH }\end{array}$ & $\begin{array}{l}\text { Intracerebral hematoma, SAH, diffuse brain } \\
\text { edema, subfalcine ( } 6 \mathrm{~mm}) \text { and tonsiller } \\
\text { herniation, brain stem comprresion. }\end{array}$ & $\operatorname{ICF}(-)$ & $\begin{array}{l}\text { White matter: } 0.284 \\
\text { Gray matter: } 0.500 \\
\text { cerebellum: } 0.336\end{array}$ & $\begin{array}{c}\text { Died within } \\
48 \text { hrs }\end{array}$ \\
\hline $41 / \mathrm{K}$ & $\begin{array}{c}\text { Viral } \\
\text { encephalitis }\end{array}$ & $\begin{array}{l}\text { Bilateral occipital and temporal } \\
\text { lob ischemia, diffuse brain edema, } \\
\text { tonsillar herniation, brainstem compresion. }\end{array}$ & $\operatorname{ICF}(-)$ & $\begin{array}{l}\text { White matter: } 0.230 \\
\text { Gray matter: } 0.448 \\
\text { cerebellum: } 0.415\end{array}$ & $\begin{array}{l}\text { Died within } \\
6 \text { days }\end{array}$ \\
\hline $63 / \mathrm{E}$ & $\begin{array}{l}\text { Intracranial } \\
\text { bleeding }\end{array}$ & $\begin{array}{l}\text { Brain stem, thalamic and intraventricular } \\
\text { hematom, diffuse brain edema, tonsillar } \\
\text { herniation, brain stem compresion. }\end{array}$ & ICF (-) & $\begin{array}{l}\text { White matter: } 0.229 \\
\text { Gray matter: } 0.412 \\
\text { cerebellum: } 0.411\end{array}$ & $\begin{array}{l}\text { Died within } \\
24 \text { hrs }\end{array}$ \\
\hline $21 / K$ & $\begin{array}{c}\text { Acute } \\
\text { anterior MI }\end{array}$ & $\begin{array}{l}\text { Diffuse brain edema, tonsillar } \\
\text { herniation, brain stem compresion }\end{array}$ & $\operatorname{ICF}(-)$ & $\begin{array}{l}\text { White matter: } 0.252 \\
\text { Gray matter: } 0.520 \\
\text { cerebellum: } 0.468\end{array}$ & $\begin{array}{l}\text { Died within } \\
7 \text { days }\end{array}$ \\
\hline $15 / \mathrm{E}$ & $\begin{array}{l}\text { Car crush } \\
\text { accident }\end{array}$ & $\begin{array}{l}\text { Traumatic SAH, intracerebral hematom, } \\
\text { diffuse brain edema, tonsiller herniation, } \\
\text { brainstem compression. }\end{array}$ & $\operatorname{ICF}(-)$ & $\begin{array}{l}\text { White matter: } 0.222 \\
\text { Gray matter: } 0.463 \\
\text { cerebellum: } 0.353\end{array}$ & $\begin{array}{l}\text { Died within } \\
8 \text { days }\end{array}$ \\
\hline $21 / K$ & $\begin{array}{l}\text { Car crush } \\
\text { accident }\end{array}$ & $\begin{array}{l}\text { cerebral contusion, diffuse brain edema, } \\
\text { subfalcine ( } 4 \mathrm{~mm}) \text { and tonsillar herniation, } \\
\text { brainstem compresion. }\end{array}$ & $\begin{array}{l}\text { ICF }(-) \text {, } \\
\text { Filiform flow of } \\
\text { bilateral ICA, } \\
\text { retrograde flow } \\
\text { through left } \\
\text { ophtalmic artey. }\end{array}$ & $\begin{array}{l}\text { White matter: } 0.225 \\
\text { Gray matter: } 0.478 \\
\text { cerebellum: } 0.389\end{array}$ & $\begin{array}{l}\text { Trans-plant } \\
\text { donor }\end{array}$ \\
\hline 19/E & $\begin{array}{l}\text { Motor vehicle } \\
\text { accident }\end{array}$ & $\begin{array}{c}\text { Intracerebral hematoma, diffuse } \\
\text { brain edema, subfalsine (7 mm ) and } \\
\text { tonsillar herniation, brain stem compresion. }\end{array}$ & $\begin{array}{c}\text { ICF }(-) \text {, } \\
\text { Fliform flow of } \\
\text { Left ICA, retrograde } \\
\text { flow through left } \\
\text { ophtalmic artey. }\end{array}$ & $\begin{array}{l}\text { White matter: } 0.267 \\
\text { Gray matter: } 0.514 \\
\text { Cerebellum: } 0.467\end{array}$ & $\begin{array}{l}\text { Died within } \\
8 \text { days }\end{array}$ \\
\hline $\begin{array}{c}\text { 18/K } \\
\text { (Figure 2) }\end{array}$ & Fall down & $\begin{array}{l}\text { Traumatic SAH, subdural hematoma, } \\
\text { diffuse brain edema, subfalsine ( } 3 \mathrm{~mm}) \text { and } \\
\text { tonsiller herniation, brain stem compresion. }\end{array}$ & $\begin{array}{l}\text { ICF }(+) \\
\text { Fliform flow } \\
\text { through bilateral } \\
\text { proximal part } \\
\text { of MCA }\end{array}$ & $\begin{array}{l}\text { White matter: } 0.327 \\
\text { Gray matter: } 0.660 \\
\text { cerebellum: } 0.470\end{array}$ & $\begin{array}{l}\text { Trans-plant } \\
\text { donor }\end{array}$ \\
\hline
\end{tabular}




\section{Continued} $47 / \mathrm{E} \quad \begin{gathered}\text { Intracranial } \\ \text { opareted mass }\end{gathered}$

50/E$$
\text { opareted mass }
$$

Intracranial hemorrage

$54 / \mathrm{K}$

Postop cerebral contusion, diffuse

brain edema, subfalcine ( $3 \mathrm{~mm}$ ) and tonsillar herniation, brain stem compresion.

Postop changes, ventricular hemorrage, diffuse brain edema transtentorial and tonsillar herniation, brain stem compresion.

ICF (+),

filiform flow

through proximal part of bilateral

MCA and ACA,

after 12 hrs in the control MRA there was no flow

$\operatorname{ICF}(+)$,

filiform flow through bilateral MCA proximal part and ACA, after 24 hrs control in the MRI there was no flow.

ICF (+), Filiform flow through right MCA proximal part and basillary artery, after 24 hrs in the control MRI there was no flow.
White matter: 0.280

Gray matter: 0.493 cerebellum: 0.447

Died within $48 \mathrm{hrs}$

White matter: 0.289

Gray matter: 0.648 cerebellum: 0.459

Trans-plant donor white matter: 0.254

Gray matter: 0.480

cerebellum: 0.434
Died within

7 days

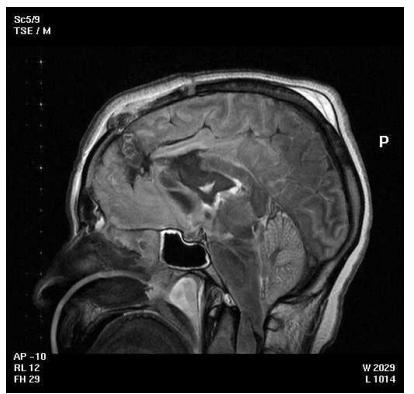

(a)

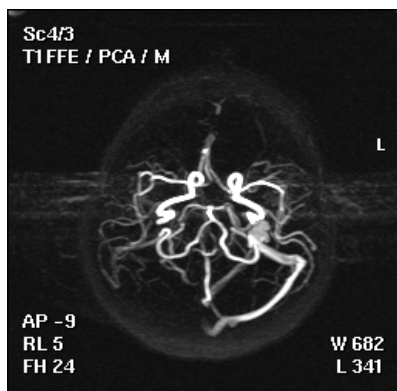

(b)

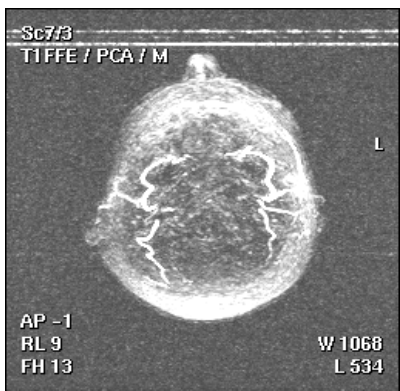

(c)

Figure 1. 51-year-old female patient: Sagittal T2 W images (a) There was diffuse edema of cerebral cortex extending to mezensefalon and pons (open arrow), also cerebellar tonsiller herniation measured $15 \mathrm{~mm}$ caudally and signs of medulla oblangata compresion (arrow); Six days before the brain death 3D MRA sequences done (b) at Willis circle there was normal intracranial flow; After brain death 3D MRA sequences done (c) intracranial flow was absent but external carotid artery and its branches (arrow).

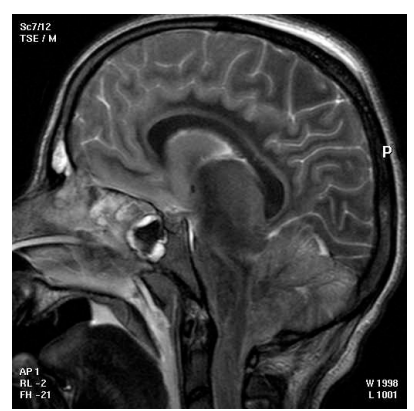

(a)

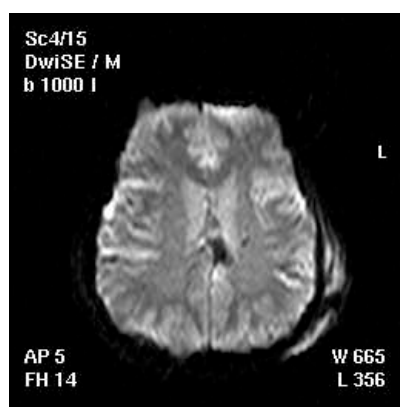

(b)

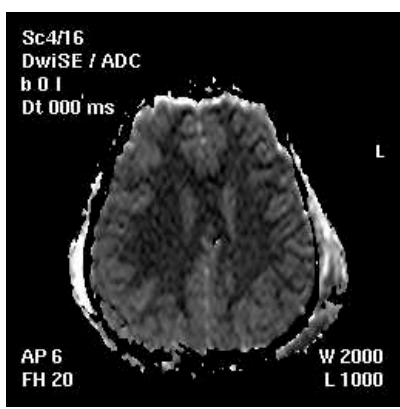

(c)

Figure 2. 18-year-old female patient. Sagittal T2 W images (a) diffuse serebral edema, hyperintense subarachnoid hemorrhage within the sulcus, tonsillar herniation and brain stem edema due to compresion (open arrow); Diffusion-weighted MR (b) DWI showed diffuse hyperintensity; ADC map demonstrates (c) diffuse drop in signal intensity and increased distinction between white-gray matter (arrow). 
sults are evaluated in 95\% level of confidence interval and $\mathrm{p}<0.05$ was accepted as statisticaly significant value.

\section{Results}

In our study, the Glasgow Coma Scale (GCS) scores of all patients were three. Clinically detected signs were; dilated or mid-dilated pupils, lack of response to light, absent corneal reflex, no response to painful stimuli, and lack of spontaneous respiratory efforts. In all patients we had a positive apnea test and excluded the conditions (metabolic disorders, drug intoxication, hypothermia, hypotension, etc.) that causes false positive results. MRI imaging of the brain performed in patients with clinical suspicion of the brain death within 3 - 24 hours after apnea test was done.

Conventional MRI sequences demonstrated generalized cerebral edema, tonsillar herniation, brainstem compression, and loss of intracranial signal void flows. Subfalcine herniation ranging 3 - $10 \mathrm{~mm}$ was seen in seven patients and also intraparenchymal hematoma, subarachnoid hemorrhage (SAH), parenchymal contusion like conditions related with coma situation.

In ten patients absence of blood flow in bilateral internal carotid arteries (ICA) and vertebral arteries were demonstrated and intracranial vascular structures. In two patients, there were retrograde flow through the ophthalmic artery and filiform drop in the cervical segment of ICA but intracranial vascular structures could not be evaluated. The absence of flow above the level of the supraclinoid portion of the internal carotid artery and in the vertebral artery where vertebral arteries enter the dura mater have been already accepted as the definitions in the diagnosis of brain death together with retrograde flow through the ophtalmic artery [4]. In two patients MRI were compatible with the absence of intracranial blood flow. In four patients we demonstrated filiform waves through the proximal parts of middle cerebral artery (MCA), anterior cerebral artery (ACA) or the basillary artery and the absence of intraparenchymal flow at the control MRI within the 12 - 24 hours. All patients had blood flow through external carotid artery and its the segments.

In one patient having SAH and intraparenchymal hematoma, we revealed the whole normal intra and extra cranial flow in the MRI, six days before the happening of clinical brain death. We observed the absence of intracranial flow in the MRI when the GCS droped to 3 points and there was suspicion of the brain death in the same patient.

In diffusion weighted MRI, we found diffuse hyperintensity of cerebral and cerebellar parenchyma, decrease in ADC values in ADC mapping and increased distiction between gray-white matter of brain. We obtained separate twenty ADC values from each white and gray matter of five lobes of brain symmetrically, bilateral basal ganglions and cerebellums both in the ten control subject and in the sixteen patients of brain death.

ADC values of normal brain were as follows: in white matter $0.660 \times 10^{-3}-0.851 \times 10^{-3} \mathrm{~mm}^{2} / \mathrm{s}$, mean value of $0.757 \pm 0.02 \times 10^{-3} \mathrm{~mm}^{2} / \mathrm{s}$; in gray matter $0.685 \times 10^{-3}-1.149 \times 10^{-3} \mathrm{~mm}^{2} / \mathrm{s}$, mean value of $0.894 \pm 0.05 \times$ $10^{-3} \mathrm{~mm}^{2} / \mathrm{s}$; in cerebellar parenchyma $0.678 \times 10^{-3}-0.742 \times 10^{-3} \mathrm{~mm}^{2} / \mathrm{s}$, mean value of $0.707 \pm 0.02 \times 10^{-3}$ $\mathrm{mm}^{2} / \mathrm{sn}$.

ADC values of the brain parenchyma with absence of intracranial blood flow in twelve patients were as follows; in white matter $0.133 \times 10^{-3}-0.395 \times 10^{-3} \mathrm{~mm}^{2} / \mathrm{s}$, mean value of $0.240 \pm 0.04 \times 10^{-3} \mathrm{~mm}^{2} / \mathrm{s}$; in gray matter $0.377 \times 10^{-3}-0.546 \times 10^{-3} \mathrm{~mm}^{2} / \mathrm{s}$, mean value of $0.455 \pm 0.03 \times 10^{-3} \mathrm{~mm}^{2} / \mathrm{s}$.

ADC values of cerebellar parenchyma in twelve patients with no blood flow were given at Table 2.

In comparison to that of the normal parenchyma, the parenchyma with absent cerebral blood flow had decreased ADC values which are statistically significant $(\mathrm{p}<0.0005)$.

The four patients who had filiform flow at the circle of Willis were evaluated as follows in white matter 0.199 $\times 10^{-3}-0.395 \times 10^{-3} \mathrm{~mm}^{2} / \mathrm{s}$, mean value $0.317 \pm 0.04 \times 10^{-3} \mathrm{~mm}^{2} / \mathrm{s}$; in gray matter $0.448 \times 10^{-3}-0.693 \times 10^{-3}$ $\mathrm{mm}^{2} / \mathrm{s}$, mean value of $0.582 \pm 0.09 \times 10^{-3} \mathrm{~mm}^{2} / \mathrm{s}$; cerebellar parenchyma $0.390 \times 10^{-3}-0.492 \times 10^{-3} \mathrm{~mm}^{2} / \mathrm{s}$, mean value $0.460 \pm 0.02 \times 10^{-3} \mathrm{~mm}^{2} / \mathrm{s}$ (Table 2 and Figure 3). In these group patients the decrease in ADC values of white matter, cerebellar parenchyma and gray matter were also statistically significant when compared with normal parenchyma (Table 2 and Figure 3).

While there is statistically significant difference between normal paranchyma with patients having no flow or filiform flow, there is no statistically significant difference between patients with absent cerebral blood flow and patients with filiform flow (Figure 3).

There was no significant difference between the two patient population for ADC values of both white matter 
Table 2. ADC values of study and control group patients $\left(\mathrm{mm}^{2} / \mathrm{s} \times 10^{-3}\right)$.

\begin{tabular}{ccccc}
\hline Patients & White matter ADC value & White matter Mean value & Gray matter ADC value & Gray matter Mean value \\
\hline${\text { Group } 1^{*}}^{*}$ & $0.133-0.395$ & $0.240 \pm 0.04$ & $0.377-0.546$ & $0.455 \pm 0.03$ \\
Group 2 $^{* *}$ & $0.199-0.395$ & $0.317 \pm 0.04$ & $0.448-0.693$ & $0.582 \pm 0.09$ \\
Normal & $0.660-0.851$ & $0.757 \pm 0.02$ & $0.685-1.149$ & $0.894 \pm 0.05$ \\
\hline
\end{tabular}

Group $1^{*}: 12$ patient with the absence of intracranial blood flow; Group $2^{* *}: 4$ patient with the fliform flow at the circle of willis.

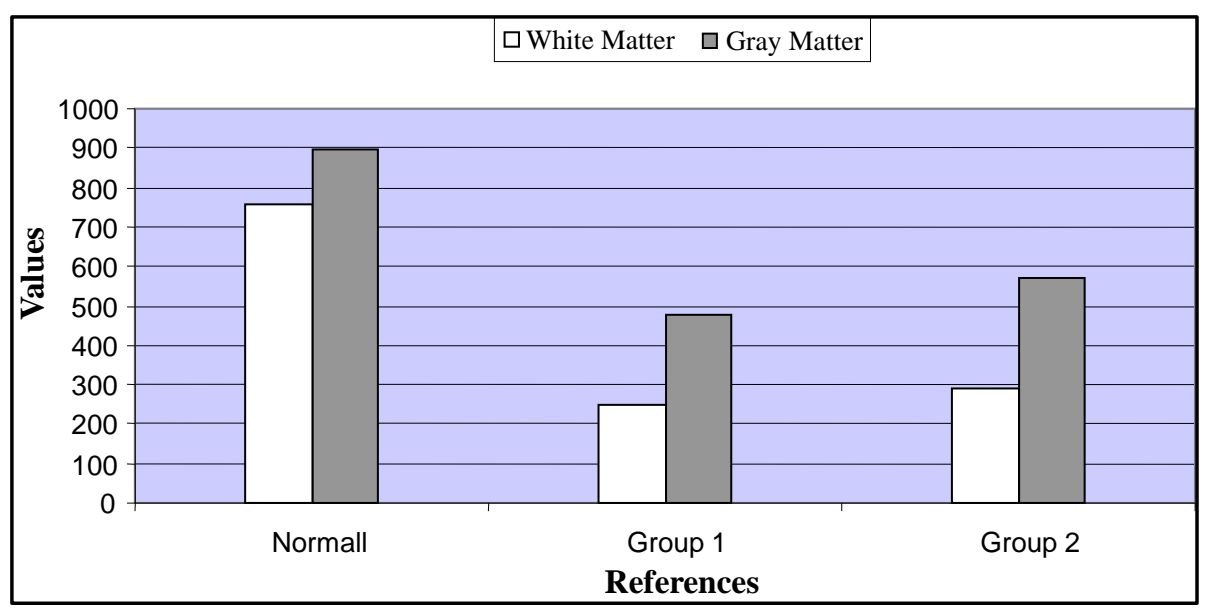

Figure 3. Comparison of ADC values.

and gray matter ( $p>0.005)$. Also, when the patients evaluated separately ADC values of cerebellar region, gray and white matter of brain parenchyma in two of four patients with intracranial blood flow were compatible with the patients lacking intracranial blood flow. Only difference between the groups was in the other two patients with intracranial blood flow in which ADC values of cerebellar region and white matter brain parenchyma were compatible, while the ADC values of gray matter was minimally increased.

In our study, the mean ADC values of the brain in dead patients were compared with normal controls of physiological ADC values of unaffected brain tissue. As a result, significant decrease of the mean ADC values observed $65 \%$ in white matter and $42 \%$ in gray matter and $45 \%$ in cerebellar parenchyma.

Sixteen patients in our study diagnosed as brain death by a committee of a cardiologist, a neurosurgeon, a neurologist, and an anesthesiologist after MRA and cranial MR evaluation. The organs of three brain death patients were donated for transplantation. In spite of intensive care unit support, the eight of the other thirteen patients had circulatory arrest following 48 hours and in five at 4 - 8 days.

In addition, MRI demonstrated tonsillar herniation, brain stem compression, brain edema, the absence of intracranial vascular flow voids in all patients diagnosed as brain death.

While intracranial vascular flow was absent in the twelve patients, in four of them there were filiformatous waves at the level of the willus circle which were disappeared in the following four hours. When we take in the consideration of the progressive nature of brain death and the studies in which intracranial blood flow void were observed [5] inspite of brain death, we decided to define those filiform waves that observed in four patients as residual waves.

It showed us that MRA is a noninvasive method which has high sensitivity and specifity to detect intracranial vascular flow.

\section{Discussion}

After recent advances in organ transplantation, there is a need to diagnose brain death with utmost accuracy and urgency. Early detection of brain death prevent the long-term follow-up in the intensive care unit and this can help organ donation before doubt of tissue viability. Confirmatory laboratory tests are done to exclude any condition that may confound clinical diagnosis of brain death. 
Brain death confirmatory tests are grouped in two as follows; documenting the absence of electrical activity of brain and demonstrating the absence of intracerebral blood flow [6]. Tests assessing the brain electrical activity may result in false readings due to electronic background noise creating innumerable artifacts, drug-induced hypothermia, intoxication [7]-[9].

Absence of intracranial blood flow is a valid sign for brain death [10] [11]. There are many studies published to evaluate intracranial flow; these studies depend on conventional angiography [12], Tc-99m-HMPAO radionuclides angiofraphy [11]-[13], transcranial Doppler [14], CT angiography [15], PET [16], MR spectroscopy [17], MR, and Diffusion-weighted MR [2].

Until the 1990s conventional angiography was considered the gold standard in the diagnosis of brain death examination [9] [15] [18]. It is an invasive method and due to its potential complications (e.g. pressure induced-contrast meterial would damage current veins in which the blood flow is completely interrupted or contrast medium may introduce any damage to candidate organs for donor trasplant), it is rarely used [9] [19]. Also position of the head in the prone position during angiography and contrast injection flow velocity of bolus injection can cause artifacts [6].

Radionuclide angiography is indicated as an ideal aid in determining brain death testing in many studies [20] [21]. This noninvasive method gives results which are also compatible with the cerebral angiography [22]. Especially, if combined with single-photon emission computed tomography (SPECT), 99 m. Tc-Exametazime (HMPAO) became an important tool for use in the setting of brain death evaluation due to better demonstration of the posterior fossa [23].

Transcranial Doppler ultrasonography (TDU) is a portable, non-invasive and relatively simple applied method. However TDU requires sufficient knowledge and experience. Head structure prevents the application of TDU in $20 \%$ of patients [24]. Many researchers published the false positive and negative findings [19] [25]. Based on all these reasons TDU does not have sufficient accuracy and precision among the other tests used for diagnosis of brain death.

Even though cerebral blood flow ceasetion is the most important criteria for the diagnosis, the other tests could detect the structural changes in the brain and are more reliable in terms of determining the etiopathology. Therefore, CT and MR imaging have major roles in neuroimaging. BT is an easily accessible method that can be applied quickly and easier at evaluation. BT findings like diffuse brain edema, herniation and the loss of intracranial contrast enhancement are confirmatory. Dominguez Roldan et al. concluded that two signs on NCCT were significantly associated with brain death [26]. These were midline shift of greater than $10 \mathrm{~mm}$ and compression of the ambient cistern. In our study however, when brain death is diagnosed there was subfalcine herniation ranging $3-10 \mathrm{~mm}$ in seven patients and tonsillar herniation in all patients. This shows that the main finding at CT in brain death is the tonsillar herniation causing compression of the brainstem.

CT angiography (CTA) and CT perfusion (CTP) application is a natural extension of the CT imaging techniques for the evaluation of brain death. Both techniques are possible with modern multi-detector helical CT scanner and easy to implement. According to Widjicks [27] CTA assists in determining brain death as an useful test and has been accepted in all European countries and in many non-European countries. Although it is not portable, it is a very effective method which carry less risk compared to DSA [28]. However, due to the use of iodinated contrast media, it carries the risk of tissue damage.

Neurological MR imaging has a revolutionary place and has been used for examination of each type of neuropathological conditions. MRI has already been shown to demonstrate phenomena such as the absence of flow voids in the internal carotid arteries, as well as absence of cerebral perfusion and increased enhancement of facial structures (e.g., the "hot nose sign"). Orrison et al. [29] published the MR criterias of brain death as follows: transtentorial herniation and foramen magnum herniation, absent intracranial vascular flow voids, poor differentiation between gray and white matter, absent intracranial enhancement, carotid artery enhancement, and the hot nose sign. In our study, in all patients that brain death occurred, diffuse brain edema, gray-white matter differentiation loss, tonsillar herniation, brain stem compression and flow absence in the vascular structures have been found with cranial MRI examination.

MRI is referred as a precise, non-invasive, reliable test to demonstrate the absence of intracranial flow at many publications [7] [30]. The greatest advantage of MRA is that no contrast agent is used and so there is no risk of end organ damage. Therefore, unlike other angiographic tests, it can be repeated in case of necessity. One of the concerns that is discussed for MRA is its low sensitivity against the slow blood flow [30]. This can lead to misinterpretations by mimicking complete occlusion [31]. However Karantanas et al. [32] demonstrated intra- 
cranial arterial circulation in 10 patients with severe closed head trauma which do not meet the clinical criteria for brain death and loss of intracranial arterial circulation in 20 patients with clinical diagnosis of brain death. Consequently, 20 patients without intracranial blood flow had been all dead. In this study marked differences on MRI findings between comatose control patients and patients with brain death, shows high sensitivity and specificity of this technique. In our study, we demonstrate complete disappearance of intracranial arterial circulation in twelve patients who are clinically diagnosed as brain death by MRI method. In addition, we observed disappearance of fliform waves that occured on MCA, ACA or basilar artery at subsequent controls of four patients. All cases except three patients for transplantation with donor support resulted in death despite of intensive care help. As a result of these findings in our study we believe that MRA has high sensitivity to show slow blood flow.

Diffusion-weighted MR has come up in the diagnosis of brain death in recent years. Only a few results obtained with some works are available on this subject in the literature. Diffusion MR is a special sequence essentially based on the molecular motion of water in tissue and thereby provides information about the integrity of the tissue. T2-weighted imaging shows brain swelling and brain edema but does not discriminate the cytotoxic and vasogenic edema. Diffusion-weighted MRI shows that the edema is of a cytotoxic nature and therefore corresponds not only to edema but also to ischemic tissue. ADC mapping helps to establish the nature of the disease since it rules out the presence of T2-weighted changes in the generation of the high signal seen on DWI (the socalled T2 shine-through effect) [33]. While diffusion MRI is thought to show irreversible damage on neural parenchyma, angiography shows only interrupted blood flow. ADC values in tissues are an indicator of pathopysiology on the molecular level the deeply ischemic nature of the changes.

In different studies ADC values of the neural parenchyma and normal age-related changes in ADC values have been investigated [34] [35]. Studies suggest that water diffusion at neural parenchyma depends on the age. Tanner et al. showed that with aging ADC values of brain decreases as in their study that they compared the adult population with newborn infants. Even in this study, among term and preterm newborn infants showed a significant difference between the ADC values [36]. Bilgili et al. observed in their study ADC values increase with advancing age in white matter of brain in adult [37]. Tanner et al. reported the mean ADC values of the white matter as $0.79 \times 10^{-3} \mathrm{~mm}^{2} / \mathrm{s}$, while the mean ADC values of gray matter as $0.87 \times 10^{-3} \mathrm{~mm}^{2} / \mathrm{s}[36] \mathrm{in} \mathrm{the}$ adult brain Jakob et al. had found in their study that mean values of white matter as $0.71 \times 10^{-3} \mathrm{~mm}^{2} / \mathrm{s}$, in gray matter as $0.90 \times 10^{-3} \mathrm{~mm}^{2} / \mathrm{s}$ [38]. Bilgili et al. determined the mean ADC values in the white matter as 0.738 $0.840 \times 10^{-3} \mathrm{~mm}^{2} / \mathrm{s}$ between the ages of $10-79$ [37]. In our study, we obtained from patients in the control group for white matter ADC values at average of $0.757 \times 10^{-3} \mathrm{~mm}^{2} / \mathrm{s}$, for gray matter at average of $0.894 \times 10^{-3}$ $\mathrm{mm}^{2} / \mathrm{s}$, and our findings were consistent with literature values.

In animal studies about stroke [39] [40] restriction of water motility demonstrated increased signal intensity on diffusion-weighted images and decrease in ADC values. However, ADC decreases do not reliably indicate tissue infarction. Even severely decreased ADC values may be seen in other situations, such as hypoglycemia, depression and status epilepticus [41] [42]. Common mechanism mechanism is the instantaneous water passage from the extracellular compartment to the intracellular compartment. As a consequence the decrease in intracellular water movement or the increased viscosity of intracellular compartment is a possible explanation for the decrease in ADC values.

For ischemic stroke, Schlaug et al. [43] found an approximate drop in the ADC of 41.7\%, corresponding to previous animal results of $30 \%$ to $60 \%$ decreases (39).

In the literature, DWI was first used by Lovblad first et al. [2]. In this study, ADC values were between 35\% and $72 \%$ (mean value, 57\%) of normal expected values by numerous measurements of cerebral and cerebellar parenchyma. Nakahara et al. studied [44] four deeply comatose patients with severe brain injury. One of their patients was diagnosed as clinically brain dead, and the patient's ADC values of gray and white matter were significantly lower than those of three other brain-injured patients. In addition, the ADC value of white matter was significantly lower than that of gray matter. Besides, Lovblad and Nakahara et al. showed that ADC values of white matter significantly lower than gray matter. Kumada et al. declared that after brain death happened in comatose patient, ADC values were 30\% - 40\% lower than those of normal measured before brain death [45]. Şener demonstrated on a patient with a diagnosis of brain death that ADC values decrease at the white matter and gray matter in a similar way and there was a significant difference between the ratio of white matter/gray matter ADC values [46]. At All these studies the same values were obtained, from brain death cases and white matter mean ADC values 0:18 to $12: 39 \times 10^{-3} \mathrm{~mm}^{2} / \mathrm{s}$, gray matter mean ADC values 0:34 to $12: 54 \times 10^{-3} \mathrm{~mm}^{2} / \mathrm{s}$ 
were reported. In our study, ADCs findings were obtained from the brain death patients we found white matter ADC mean as $0.257 \times 10^{-3} \mathrm{~mm}^{2} / \mathrm{s}$, gray matter mean as $0.498 \times 10^{-3} \mathrm{~mm}^{2} / \mathrm{s}$ and values are similar to earlier studies. Thus, we found an average decline in ADC values average of $65 \%$ in the white matter and in gray matter, of $42 \%$ according to normal parenchyma.

It is believed that the differences of ADC values between gray and white matter in the brain death is caused by differences in histological tissue. This suggests that situations that restrict the movement of water in white matter were more serious than in the cortex at 12 hours postmortem and swollen cortical tissue allows movement of water molecules relatively in a weak position. On the other hand patients with acute infarction on vascular ground have white matter and cortex that is known to be in a similar manner [47].

That is still being debated topic that whether the decline in the value of ADC points to the irreversible brain damage or not. In animal models and human studies of ischemia there are a few reports on normalization of initial diffusion restriction [48] [49]. On the other hand Miysaka et al. [50] reported that there wasn't any histological normalization and neuronal destruction was irreversible in the recovery phase of the ADC. Hassankhani et al. had found in their studies that the ADC ratio of reversible part was 0.8 - 1.1 when compared with the normal side, while the rate of ADC at irreversible sections was at lower values of 0.66 - 0.96 [51]. Schaefer et al. on a study conducted at patients who had acute anterior circulation occlusion and two shots of intra-arterial thrombolytic therapy pointed out that an infarct had developed on the follow-up MRI at the areas of less than the starting ADC value $0.58 \times 10^{-3} \mathrm{~mm}^{2} / \mathrm{s}$ and ADC ratio $0.80 \times 10^{-3} \mathrm{~mm}^{2} / \mathrm{s}$. Besides they had not seen any abnormalities on the follow-up MRI at the areas of higher than the ADC value $0.80 \times 10^{-3} \mathrm{~mm}^{2} / \mathrm{s}$ and ADC ratio 0.96 [52]. As well as our study and previous studies showed that declines of ADC values are more evident in the neural parenchyma at brain death (ADC values of patients in our study were at ratio of 0.34 in the white matter, 0.55 in gray matter when compared with normal parenchyma).

\section{Conclusions}

The ADC maps are useful techniques for recognition of global irreversible brain damage and providing additional information of severe brain-damaged patients with respect to clinical outcomes.

MRI can detect and explain underlying pathology causing brain death. Also MRA is a noninvasive method which has high sensitivity and specifity to detect intracranial vascular flow.

\section{References}

[1] (1968) Ad Hoc Committee of Harvard Medical School to Examine the Definition of Brain Death: A Definition of İrreversible Coma. JAMA, 205, 337-340. http://dx.doi.org/10.1001/jama.1968.03140320031009

[2] Lovblad, K. and Bassetti, C. (2000) Diffusion-Weighted Magnetic Resonance İmaging in Brain Death. Stroke, 31, 539542. http://dx.doi.org/10.1161/01.STR.31.2.539

[3] Douek, P., et al. (1991) MR Color Mapping of Myelin Fiber Orientation. Journal of Computer Assisted Tomography, 15, 923-929. http://dx.doi.org/10.1097/00004728-199111000-00003

[4] Greitz, T., et al. (1973) Aorto-Cranial and Carotid Angiography in Determination of Brain Death. Neuroradiology, 5, 13-19. http://dx.doi.org/10.1007/BF02464624

[5] Palmer, S. and Bader, M.K. (2005) Brain Tissue Oxygenation in Brain Death. Neurocritical Care, 2, 17-22. http://dx.doi.org/10.1385/NCC:2:1:017

[6] Monsein, L.H. (1995) The İmaging of Brain Death. Anaesthesia and Intensive Care, 23, 44-50.

[7] Jones, K. and Barnes, P.D. (1992) MR Diagnosis of Brain Death. American Journal of Neuroradiology, 13, 65-66.

[8] Paolin, A., et al. (1995) Reliability in Diagnosis of Brain Death. Intensive Care Medicine, 21, 657-662. http://dx.doi.org/10.1007/BF01711544

[9] Facco, E., et al. (1998) Tc-HMPAO SPECT in the Diagnosis of Brain Death. Intensive Care Medicine, 24, 911-917. http://dx.doi.org/10.1007/s001340050689

[10] Goodman, J.M., Heck, L.L. and Moore, B.D. (1985) Confirmation of Brain Death with Portable İsotope Angiography: A Review of 204 Consecutive Cases. Neurosurgery, 16, 492-497. http://dx.doi.org/10.1227/00006123-198504000-00010

[11] Holzman, B.H., Curless, R.G., Sfakianakis, G.N., Ajmone-Marsan, C. and Montes, J.E. (1983) Radionuclide Cerebral Perfusion Scintigraphy in Determination of Brain Death in Children. Neurology, 33, 1027.

http://dx.doi.org/10.1212/WNL.33.8.1027 
[12] Gomes, A. and Hallinan, J. (1983) Intravenous Digital Subtraction Angiography in the Diagnosis of Brain Death. American Journal of Neuroradiology, 4, 21-24.

[13] de la Riva, A., González, F.M., Llamas-Elvira, J.M., Latre, J.M., Jimenez-Heffernan, A., Vidal, E., et al. (1992) Diagnosis of Brain Death: Superiority of Perfusion Studies with ${ }^{99} \mathrm{Tc}^{\mathrm{m}}$-HMPAO over Conventional Radionuclide Cerebral Angiography. British Journal of Radiology, 65, 289-294. http://dx.doi.org/10.1259/0007-1285-65-772-289

[14] Petty, G.W., Mohr, J.P., Pedley, T.A., Tatemichi, T.K., Lennihan, L., Duterte, D.I. and Sacco, R.L. (1990) The Role of Transcranial Doppler in Confirming Brain Death: Sensitivity, Specificity, and Suggestions for Performance and İnterpretation. Neurology, 40, 300. http://dx.doi.org/10.1212/WNL.40.2.300

[15] Dupas, B., Gayet-Delacroix, M., Villers, D., Antonioli, D., Veccherini, M.F. and Soulillou, J.P. (1998) Diagnosis of Brain Death Using Two-Phase Spiral CT. American Journal of Neuroradiology, 19, 641-647.

[16] Momose, T., Nishikawa, J., Watanabe, T., Ohtake, T., Sasaki, Y., Sasaki, M. and Mii, K. (1992) Clinical Application of 18F-FDG-PET in Patients with Brain Death. Kaku İaku Japanese Journal of Nuclear Medicine, 29, 1139-1142.

[17] Garde, K., Mortensen, A.C., Toft, P.B., Sørensen, M.B., Madsen, F.F. and Henriksen, O. (1994) Phosphorus and Proton Spectroscopy in Relation to Near İncarceration and İncarceration of the Human Brain. Acta Radiologica, 35, 197-200. http://dx.doi.org/10.3109/02841859409172364

[18] Wijdicks, E.F.M. (2001) The Diagnosis of Brain Death. New England Journal of Medicine, 344, 1215-1221. http://dx.doi.org/10.1056/NEJM200104193441606

[19] Nau, R., Prange, H.W., Klingelhöfer, J., Kukowski, B., Sander, D., Tchorsch, R. and Rittmeyer, K. (1992) Results of Four Technical İnvestigations in Fifty Clinically Brain Dead Patients. Intensive Care Medicine, 18, 82-88. http://dx.doi.org/10.1007/BF01705037

[20] Shemie, S.D., Doig, C., Dickens, B., Byrne, P., Wheelock, B., Rocker, G., et al. (2006) Severe Brain İnjury to Neurological Determination of Death: Canadian Forum Recommendations. Canadian Medical Association Journal, 174, S1-S12. http://dx.doi.org/10.1503/cmaj.045142

[21] Okuyaz, C., Gücüyener, K., Karabacak, N.İ., AydIn, K., SerdaroĞlu, A. and Cingi, E. (2004) Tc-99m-HMPAO SPECT in the Diagnosis of Brain Death in Children. Pediatrics International, 46, 711-714. http://dx.doi.org/10.1111/j.1442-200x.2004.01976.x

[22] Munari, M., Zucchetta, P., Carollo, C., Gallo, F., De Nardin, M., Marzola, M.C., Ferretti, S. and Facco, E. (2005) Confirmatory Tests in the Diagnosis of Brain Death: Comparison between SPECT and Contrast Angiography. Critical Care Medicine, 33, 2068-2073. http://dx.doi.org/10.1097/01.CCM.0000179143.19233.6A

[23] Weckesser, M. and Schober, O. (1999) Brain Death Revisited: Utility Confirmed for Nuclear Medicine. European Journal of Nuclear Medicine, 26, 1387-1391. http://dx.doi.org/10.1007/s002590050469

[24] Young, G.B. and Lee, D. (2004) A Critique of Ancillary Tests for Brain Death. Neurocritical Care, 1, 499-508. http://dx.doi.org/10.1385/NCC:1:4:499

[25] Rodriguez, R.A., Cornel, G., Alghofaili, F., Hutchison, J. and Nathan, H.J. (2002) Transcranial Doppler during Suspected Brain Death in Children: Potential Limitation in Patients with Cardiac Shunt. Pediatric Critical Care Medicine, 3, 153-157.

[26] Dominguez-Roldan, J.M., Jimenez-Gonzalez, P.I., Garcia-Alfaro, C., Hernandez-Hazañas, F., Murillo-Cabezas, F. and Perez-Bernal, J. (2004) Identification by CT Scan of İschemic Stroke Patients with High Risk of Brain Death. Transplantation Proceedings, 36, 2562-2563. http://dx.doi.org/10.1016/j.transproceed.2004.11.071

[27] Wijdicks, E.F. (2002) Brain Death Worldwide: Accepted Fact but No Global Consencus in Diagnostic Criteria. Neurology, 58, 20-25. http://dx.doi.org/10.1212/WNL.58.1.20

[28] Quality Standards Subcommittee of the American Academy of Neurology (1995) Practice Parameters for Determining Brain Death in Adults (Summary Statement). Neurology, 45, 1012-1014. http://dx.doi.org/10.1212/WNL.45.5.1012

[29] Orrison, W.W., Champlin, A.M., Kesterson, O.L., Hartshorne, M.F. and King, J.N. (1994) MR “Hot Nose Sign” and “Intravascular Enhancement Sign” in Brain Death. AJNR American Journal of Neuroradiology, 15, 913-916.

[30] Ishii, K., Onuma, T., Kinoshita, T., Shiina, G., Kameyama, M. and Shimosegawa, Y. (1996) Brain Death: MR and MR Angiography. AJNR American Journal of Neuroradiology, 17, 731-735.

[31] Brant-Zawadzki, M. (1990) Routine MR İmaging of the İnternal Carotid Artery Siphon: Angiographic Correlation with Cervical Carotid Lesions. American Journal of Neuroradiology, 11, 467-471.

[32] Karantanas, A.H., Hadjigeorgiou, G.M., Paterakis, K., Sfiras, D. and Komnos, A. (2002) Contribution of MRI and MR Angiography in Early Diagnosis of Brain Death. European Radiology, 12, 2710-2716.

[33] Schaefer, P.W., Buonanno, F.S., Gonzalez, R.G. and Schwamm, L.H. (1997) Diffusion-Weighted İmaging Discriminates between Cytotoxic and Vasogenic Edema in a Patient with Eclampsia. Stroke, 28, 1082-1085. http://dx.doi.org/10.1161/01.STR.28.5.1082 
[34] Engelbrecht, V., Scherer, A., Rassek, M., Witsack, H.J. and Mödder, U. (2002) Diffusion-Weighted MR İmaging in the Brain in Children: Findings in the Normal Brain and in the Brain with White Matter Diseases. Radiology, 222, 410-418. http://dx.doi.org/10.1148/radiol.2222010492

[35] Forbes, K.P., Pipe, J.G. and Bird, C.R. (2002) Changes in Brain Water Diffusion during the 1st Year of Life. Radiology, 222, 405-409. http://dx.doi.org/10.1148/radiol.2222010179

[36] Tanner, S.F., Ramenghi, L.A., Ridgway, J.P., Berry, E., Saysell, M.A., Martinez, D., et al. (2000) Quantitative Comparison of İntrabrain Diffusion in Adults and Preterm and Term Neonates and İnfants. American Journal of Roentgenology, 174, 1643-1649. http://dx.doi.org/10.2214/ajr.174.6.1741643

[37] Karadeniz Bilgili, Y.M., Ünal, B., Kendi, T., Simflir, İ., Erdal, H., Huvaj, S., Kara, S. and Bademci, G. (2004) MRG ile normal görünümlü beyaz ve gri cevherde yaşlanmanın etkilerinin ADC değerleri ile saptanabilirliği. Tanısal ve Giriflimsel Radyoloji, 10, 4-7.

[38] Jakob, P.M., et al. (1997) Single-Shot Diffusion Weighted İmaging of the Brain with HASTE. In: Oudkerk, M. and Edelman, R., Eds., High-Power Gradient MR-Imaging Advances in MRI. II, Blackwell Science, London, 177-181.

[39] Hoehn-Berlage, M., Norris, D.G., Kohno, K., Mies, G., Leibfritz, D. and Hossmann, K.A. (1995) Evolution of Regional Changes in Apparent Diffusion Coefficient during Focal İschemia of Rat Brain: The Relationship of Quantitative Diffusion NMR İmaging to Reduction in Cerebral Blood Flow and Metabolic Disturbance. Journal of Cerebral Blood Flow \& Metabolism, 15, 1002-1011. http://dx.doi.org/10.1038/jcbfm.1995.126

[40] Moseley, M.E., Cohen, Y., Mintorovitch, J., Chileuitt, L., Shimizu, H., Kucharczyk, J., et al. (1990) Early Detection of Regional Cerebral İschemia in Cats: Comparison of Diffusion- and T2-Weighted MRI and Spectroscopy. Magnetic Resonance in Medicine, 14, 330-346. http://dx.doi.org/10.1002/mrm.1910140218

[41] Röther, J., de Crespigny, A.J., D’Arceuil, H. and Moseley, M.E. (1996) MR Detection of Cortical Spreading Depression İmmediately after Focal İschemia in the Rat. Journal of Cerebral Blood Flow \& Metabolism, 16, $214-220$. http://dx.doi.org/10.1097/00004647-199603000-00005

[42] Baird, A.E. and Warach, S. (1998) Magnetic Resonance İmaging of Acute Stroke. Journal of Cerebral Blood Flow \& Metabolism, 18, 583-609. http://dx.doi.org/10.1097/00004647-199806000-00001

[43] Schlaug, G., Siewert, B., Benfield, A., Edelman, R.R. and Warach, S. (1997) Time Course of the Apparent Diffusion Coefficient (ADC) Abnormality in Human Stroke. Neurology, 49, 113-119. http://dx.doi.org/10.1212/WNL.49.1.113

[44] Nakahara, M., Ericson, K. and Bellander, B.M. (2001) Diffusion-Weighted MR and Apparent Diffusion Coefficient in the Evaluation of Severe Brain İnjury. Acta Radiologica, 42, 365-369. http://dx.doi.org/10.1080/028418501127346990

[45] Kumada, K., Fukuda, A., Yamane, K., Horiuchi, I., Kohama, A., Hirano, K. and Onoda, T. (2001) Diffusion-Weighted İmaging of Brain Death: Study of Apparent Diffusion Coefficient. Nō to Shinkei, 53, 1027-1031.

[46] Sener, R.N. (2004) Diffusion MRI in the Postmortem Brain: Case Report. Journal of Neuroradiology, 31, $406-408$. http://dx.doi.org/10.1016/S0150-9861(04)97025-3

[47] McKinney, A.M., Teksam, M., Felice, R., Casey, S.O., Cranford, R., Truwit, C.L. and Kieffer, S. (2004) DiffusionWeighted İmaging in the Setting of Diffuse Cortical Laminar Necrosis and Hypoxic-İschemic Encephalopathy. American Journal of Neuroradiology, 25, 1659-1665.

[48] Beauchamp, N.J., Ulug, A.M., Passe, T.J. and van Zijl, P.C. (1998) MR Diffusion İmaging in Stroke: Review and Controversies. RadioGraphics, 18, 1269-1283. http://dx.doi.org/10.1148/radiographics.18.5.9747619

[49] Karonen, J.O., Liu, Y., Vanninen, R.L., Østergaard, L., Kaarina Partanen, P.L., Vainio, P.A., et al. (2000) Combined Perfusion- and Diffusion-Weighted MR İmaging in Acute İschemic Stroke during the First Week: A Longitudinal Study. Radiology, 217, 886-894. http://dx.doi.org/10.1148/radiology.217.3.r00dc02886

[50] Miyasaka, N., Kuroiwa, T., Zhao, F.Y., Nagaoka, T., Akimoto, H., Yamada, I., et al. (2000) Cerebral İschemic Hypoxia: Discrepancy between Apparent Diffusion Coefficients and Histologic Changes in Rats. Radiology, 215, 199204. http://dx.doi.org/10.1148/radiology.215.1.r00ap24199

[51] Hassankhani, A., et al. (2001) Value of Diffusion Weighted İmaging in Predicting the Final Size of İschemic Core Following Thrombolysis. In: Book of Abstracts: 87th Scientific Assembly of the Radiological Society of North American, Chicago, 25-30 November 2001.

[52] Schaefer, P.W., Hassankhani, A., Putman, C., Sorensen, A.G., Schwamm, L., Koroshetz, W. and Gonzalez, R.G. (2004) Characterization and Evolution of Diffusion MR İmaging Abnormalities in Stroke Patients Undergoing İntra-Arterial Thrombolysis. American Journal of Neuroradiology, 25, 951-957. 